\section{E A Institute of \\ YK Business Administration \\ 光 \\ Karachi \\ Leadership and Ideas for Tomorrow}

\section{Business Review}

Volume 3 Issue 1 January-June 2008

$1-1-2008$

\title{
Front Matter of Volume 3 Number 1
}

Tufail A. Qureshi

Institute of Business Administration, Karachi, Pakistan

Follow this and additional works at: https://ir.iba.edu.pk/businessreview

Part of the Business Commons

cc) (†)

This work is licensed under a Creative Commons Attribution 4.0 International License.

\section{Recommended Citation}

Qureshi, T. A. (2008). Front Matter of Volume 3 Number 1. Business Review, 3(1), 2-6. Retrieved from https://doi.org/10.54784/1990-6587.1128

This article is brought to you by iRepository for open access under the Creative Commons Attribution 4.0 License and is available at https://ir.iba.edu.pk/businessreview/vol3/iss1/2. For more information, please contact irepository@iba.edu.pk. 
Volume 3 Number 1

\section{Business Review}

January - June 2008

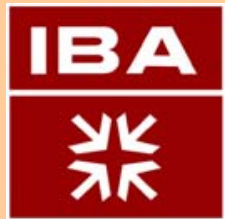

RESEARCH JOUNAL

of

THE INSTITUTE OF BUSINESS ADMINISTRATION KARACHI - PAKISTAN. 


\title{
Business Review
}

\author{
IBA \\ 率
}

\section{RESEARCH JOURNAL} of

\section{THE INSTITUTE OF BUSINESS ADMINISTRATION} KARACHI - PAKISTAN 


\section{IBA \\ 戗}

\section{Business Review}

Editorial Board

Danishmand

Director
Tufail A. Qureshi

Editor

\section{Advisory Board}

Khadija Malik Bari

Talat A. Wazarat

Zeenat Ismail

Institute of Business Administration, Karachi, Pakistan
Javed Hussain

Mirza Sardar Hussain

Naved Ahmed

\section{External Editors}

Akif Hassan

IQRA University, Karachi, Pakistan

Abdul Rashid

International Islamic University, Islamabad, Pakistan

\section{Consulting Foreign Editors}

Deepak Kapur

Institute of Management Technology

Ghaziabad, UP, India

Low Sui Pheng

National University of Singapore

Singapore

S.W.S.B. Dasanayaka

University of Moratuwa

Sri Lanka

Toshio Fujita

Japan International Cooperation Agency

Tokyo, Japan
Arun Diwaker Nath Bajpai

Rani Durgavati University

Jabalpur, MP, India

Khurshid M.Kiani

Bang College of Business

Almaty, Republic of Kazakhstan

Bettina Robotka

Humbolt University Berlin

Germany

Khursheed Omer

University of Houston

Downtown Texas, USA

Faisal Manzoor Arain

University of Calgary, Canada 
Volume 3 Number 1

\section{O N T E N T S}

Editorial Perspective.

\section{ARTICLE}

Is Good will Impairment Loss Meaningful Information?

Orapin Duangploy, Khursheed Omer, Justo Manrique and Margaret Shelton.

Institution of Bureaucracy and The Conflict in South Asia: Huma Baqai.

Effects of Free Trade Agreements (FTAs) on Construction Firms in Singapore:

Low Sui Pheng and June S.Y. Khoo.

Economic Reforms and Total Factor Productivity Growth in Pakistan: An Empirical Analysis:

Muhammad Sabir and Qazi Masood Ahmed.

SMEs in Globalized World: A Brief Note on Basic Profiles of Pakistan’s Small and Medium Scale

Enterprises and Possible Research Directions: Sarath W.S.B. Dasanayaka.

On Nonlinearities in KSE 100 Index Stock Return: Khurshid M. Kiani....

\section{Discussions}

Training within Oil and Gas-Based Industries in the State of Qatar: Hend A. Jolo

Managing Knowledge Worker: Shandana Shuaib.

Gradient-Based Edge Detection on a Hexagonal Structure: Xiangjian, Tom Hintz,

Qiang Wu and Wenjing Jia.

The Role of Governance and Its Influence on Quality Enhancing Mechanism in Higher Education:

Syed Naeem Ahmed.

Spiritual Basis of Worldly Success: Dr.iur.Menno Aden

\section{Case Studies}

Pilot Study of 8 SMEs in Pakistan: Ejaz Ahmed Mian .165

A Word About the IBA 195

Publications Received 207
About our Authors 201

Note for Contributors 205 


\section{Editorial Perspective}

\author{
Call the world if you please \\ "The Vale of soul-making". \\ Then you will find out \\ the use of the world.
}

John Keats

\begin{abstract}
Tt has been justly observed that Drucker is a "painter of concepts." In a less artistic I way, we may also add that as a philosopher of business management he was deeply concerned with the reconstruction of the conceptual structure of corporate thought. However, the observation made about him, so poignant in condensation, has vast ramification in the fields of teaching and research. As an attitude, it says much more than words could ever say. Drawn into the context of teaching and research, it bears upon the situation in which concepts without percepts are philosophically barren and blind and percepts without concepts are empty and devoid of pedagogical significance. Together, the conceptual structures of our perceptual organizations reflect upon the curiosity of an inquiring mind wanting to reach beyond the ken of its comprehension. Simultaneously, they identify the élan vital, the vital urge, of the transcending vision to see beyond the last horizon in anticipation of the yet to be.
\end{abstract}

In the domain of our conceptual framework, if the painter of mental terrain is content with the world as it is, he is not a painter but a captive of a single vision. A real painter is one who suffers from creative discontent with the "given" world, i.e., the world as it is. He paints a picture of the world not as it is but as it ought to be. His concepts and ideas are an intermediate between the "thus it is" and "thus it is not", between the given world and the world to be. Such a transcending vision unfolds the anticipations which make the worldly existence an unrepeatable once in a life-time venture. It shows that there exists a dynamic relationship between our concept of the world and our way of circumstancing our situated existence in the world. It is in the light of our beliefs about the nature of the world, i.e., our world-view, that we formulate our conceptions of the norms and values that govern the worldliness of the world. And these concepts define the parameters within which we frame our conduct in relation to our being-in-the-world.

Our being-in-the-world is a reflection of the values we live by and the nature of the preposition in defines our way of circumstancing the world. A man and his predator are both in the world but not in the same manner of being. It seems that the "world" is a misnomer when it is applied to the world concept. The 'world', if it is not a lived-world, means nothing and does not exist. There is no such place as the world. There are as many worlds as there are ways of being-in-the world. The concept of

2 
the world therefore is relative to our way of making the world our own. We do not live in different worlds but we live in the same world differently. Iqbal made the phenomenological concept of the lived-world strikingly clear;

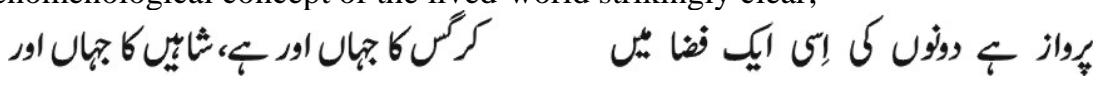

Such transcendental movement lies at the heart of research orientation, as well as tacit and contextual learning and teaching. As an integral component of the teaching methodology, transcending vision characterizes a continuous and incremental improvement. It enlarges our perspective on life and deepens our world-view.

When we embarked upon the publication of Business Review we stressed the need for a collaborative and interdisciplinary eclectic research culture. It continues to be our cherished vision. We believe that in research, as in teaching and learning and more so in life, we should not remain captive of our own narrow vision, unexamined assumptions and unquestioned presuppositions. They can, as they always do, blur and distort our perception of truth and reality. In our search for reality and in our romance with truth, we must therefore take a phenomenologically radical attitude towards self-exploration and self-examination, as an essential feature of our research methodology. Moreover, to augment authentic research awareness we must draw into our business curriculum a recognition of the role humanities and social sciences play in the formulation of a corporate world-view, providing it ethical and moral foundation.

Research initiates the advent of new ideas and the beginning of new knowledge. It takes us into the realm of understanding not yet envisioned by the human mind. The anticipatory attitude and the creative joy of research thrives on the gestaltan awareness of the perspectival variation, unfolding the possibilities inherent in the structure of our forward looking movement towards the yet-to-be. Research unfolds the horizons still unmarked by the footprints of human imagination. By demolishing the existing barriers, it pushes the forbidding boundaries further and farther still. Methodologically, that is how research adds new meanings, new values and new ideals to our being-in-the-world; enlarging the familiar meaning of the world. Such value added conceptual knowledge acquires significance in and through its extension into the "world-making" and "world-shaking" acts. The socio-cultural construction of reality is predicated upon the meaning intending and evaluative nature of the constitutive intentionality of our consciousness. The notion of intentional constitution must therefore be drawn into the fold of the concept of corporate reality in order to have a clear and distinct perception of the corporate world-view. The constitution of corporate reality gains significance against the backdrop of our research imperatives becoming increasingly focused on the concept of moral responsibility embedded in the Paradigm of our corporate world-view. Value based knowledge leads to the anticipation of thus it ought to be. When research is conducted with such creative passion, it colours our dreams and brighten the dawn of 
the world-to-be. Our success and failure in this regard will depend entirely upon two things. Firstly, to put it in the Qur'anic parlance, a whole hearted willingness to accept social responsibility for our portion of the world. And, secondly, the invincibility of our political will to translate the existing social issues into ethical issues in order to provide moral foundation to our worldly condition. Again, it means two things. Firstly, the need to draw hermeneutic and axiological principles into the pedagogical philosophy of our business education. And, secondly, to devise and develop a teaching methodology incorporating diverse philosophies, theories and research designs and methods as one of its strengths. The aim should be to inculcate ethical vision and moral proclivity into our corporate culture suffering from congenital self-aggrandisement, voracious and greedy consumerism, self-interest and profit-ridden commercialism. In the light of postmodernist social critiques, it is now becoming more and more evident that we cannot outline the contours of a corporate philosophy of life and culture without drawing into our business education the values which are integral to the ethos of moral character and the discipline of corporate social responsibility and adult maturity.

The culture of corporate society and academic scholarship is heterogeneous with overlapping domains of practice and knowledge that need not be antithetical in their ethico-moral orientation, especially within the disciplinary communities such as education, sociology and humanities. The need for interdisciplinary areas of study cannot be over stressed in qualitative research in the realm of corporate culture. The leadership role in this regard goes again to Drucker, a philosopher of management, whose ideas embrace the 'how' and the 'what' of corporate thinking. His vision is informed by overlapping concepts, converging upon diverse issues of business society replete with profound significance in the field of business education. Together, they present a uniquely exciting picture of the "Knowledge Society", a futuristic vision of the corporate world.

The glory and greatness of a society and the feeling of guilt and shame of man's failure as a man, provide us with a glimpse into the mind and soul of an age. History of ideas and its connection with the lived-world reveals the structural problems, strengths and weaknesses, and also the creative and defining compulsions inherent in a given paradigm. The stunning collapses and breakdowns of Maxwell, BCCI, Polly Peck and others in the UK, USA and elsewhere and the rise and fall of Enron, have left us wondering about the baffling nature of the ethical and moral flaws inherent in the corporate world-view. Events such as these present powerful indictment of the corporate system suffering from foundational stress.

It is now becoming more and more evident that in a self-sustaining corporate worldview, the moral education of our managers, administrators and business executives ought to be an essential component of their role in society. Ironically, in the existing state of affairs, the place of ethics and moral disposition in our business education 
leaves much to be desired. In order to be true to our calling, we need to integrate Business Ethics as a core subject into our syllabus. However, to make such an ideal the summum bonum of our corporate world-view, we must approach the issue with joyful wisdom, to say the things we need to say, to think the thoughts we ought to think. In a constantly changing "world", the things which matter most are the things which make a difference in our life. Our choices and decisions can radically alter and change our ways of being-in-the-world. Robert Frost has beautifully expressed the poetics of such an experience thus. "I shall be telling this with a sigh somewhere ages and ages hence: Two roads diverged in wood, and I took the one less travelled by, And that has made all the difference." "Knowing how way leads on to way", seeking the goal we are seeking, let us keep in mind the following markings:

- the need to work ethics and moral vision into the executive orientation and evaluative judgements of our business management,

- realizing the philosophical refrain that in order to grow ethically and morally and to add value dimension to our corporate world-view, we need to outgrow our existing disregard and apathy for the humanities,

- and in this regard, exert the creative will to remove from our business education the stigma that the ideal of moral education and ethical persuasion does not harmonize with economic motivation and that such an ideal of business education rests on a scheme of teaching and learning which is un-pragmatic and unpractical,

- knowing that the truth is always out there, within the reach of our reflexive awareness, inviting us - the exponents of morality in business education to display the wisdom to expose our students to such a catalytic educational experience and to make it the best it can possibly be,

- $\quad$ and to resist no more the passion to critically and creatively will the truth in order to combat the stultifying concepts and falsifications which have crept into the belief that in the scheme of our executive disposition, the propensity for business management and decision making does not correlate with the ethical and moral predilection,

- $\quad$ and then to decisively set aside the dubious belief that in a business society success depends upon manipulation of social norms and cultural sensibilities, exploitation of executive power, idealization of shallow pragmatic belief in the expedient workability of ideas and an obsessively over-riding concern with profit and more profit resulting in a schizophrenic disregard for ethical norms and moral values,

- to realize the existential truth that, in the end, it does not profit a man if he gains the whole world but loses his soul. We must therefore exercise moral exertion to outgrow the fixation on equating economic life with money.

It is pertinent to note, as Jack Beatty in his The World According to Drucker has very aptly pointed out: 
"Drucker discusses economic life in terms of values, integrity, character, knowledge, vision, responsibility, self-control, social integration, teamwork, community, competence, social responsibility, the quality of life, self-fulfillment, leadership, duty, purpose, dignity, meaning - but rarely money. He defends profit, but as if it were broccoli: a distasteful obligation of managers who would rather be reading Kierkegaard.”

Drawn into a road map, the distinctive features outlined above will define the dynamic and creative markings of the corporate world-view. They will generate the pragmatic attitude of using our moral edge for sustainable competitive advantage and profitability. No matter how entirely self-serving in their motivational disposition, attitudes, decisions and ideals, the defining features stipulated above must serve as the essential categories of corporate thinking. Cognitively, such an approach is hermeneutically necessary at any given stage of our business education in order to move to still higher stages of the development of the ethos of our corporate culture. Such a radically altered way of thinking will help us understand that the corporate culture need not be averse to the longings of ethical sensibilities and the yearnings of moral character. By no means should they be antagonistic or antithetical to the practical strivings of corporate compulsions. In fact they should make a compelling case for the assumption that in order to become embedded in the curriculum of our business education, our corporate world-view needs to be a moving target, unfolding always the freshness of the world-to-be.

In the words of T.S. Eliot,

"We must not cease from exploration and the end of all our exploring will be to arrive where we began and to know the place for the first-time.” 